\title{
KAJIAN BAKU MUTU LOGAM BERAT DI UDARA AMBIEN SEBAGAI BAHAN MASUKAN LAMPIRAN PP 41/1999 TENTANG PENGENDALIAN PENCEMARAN UDARA
}

\author{
STUDY OF QUALITY STANDARD OF HEAVY METAL IN AMBIENT \\ AIR FOR PROPOSING APPENDIX OF GOVERNMENT REGULATION \\ PP41/1999 ON AIR POLLUTION CONTROL
}

\author{
Rita Mukhtar ${ }^{1}$, Susy Lahtiani ${ }^{1}$, Esrom Hamonangan ${ }^{1}$, Hari Wahyudi ${ }^{1}$, \\ Muhayatun Santoso², Diah Dwiana Lestiani²
}

(Diterima tanggal 30-10-2013; Disetujui tanggal 02-01-2014)

\begin{abstract}
ABSTRAK
Logam berat yang terkandung di dalam udara ambien khususnya partikulat udara $\mathrm{PM}_{25}$ dapat membahayakan manusia karena ukuran $\mathrm{PM}_{2.5}$ memungkinkannya untuk berpenetrasi menembus bagian terdalam dari paru-paru dan sistem jantung dan menyebabkan berbagai gangguan kesehatan, seperti infeksi saluran pernafasan akut, kanker paru-paru, penyakit kardiovascular bahkan kematian. Dalam PP No. 41/1999 tentang pengendalian pencemaran udara telah tercantum baku mutu logam berat di udara ambien namun baru terbatas pada logam timbal $(\mathrm{Pb})$ sedangkan logam berbahaya lainnya seperti arsen (As), kadmium (Cd), merkuri (Hg), kromium (Cr), mangan (Mn), dan nikel (Ni) belum diatur dalam PP tersebut. Sehingga perlu dilakukan kajian logam berat dalam partikulat udara ambien $\mathrm{PM}_{2.5}$ sebagai bahan dasar ilmiah dalam rangka revisi Lampiran PP 41/199 tersebut. Selain itu, nilai baku mutu yang telah diatur dalam PP tersebut perlu ditinjau kembali untuk melihat kesesuaiannya dengan kondisi lingkungan atau udara ambien saat ini. Adapun usulan yang disampaikan dalam rangka revisi Lampiran PP 41/1999 tentang pengendalian pencemaran udara adalah parameter logam berat yang berada pada partikulat udara ukuran TSP dan PM $_{2.5}$ yaitu baku mutu Pb pada TSP diperketat menjadi $0.5 \mu \mathrm{g} / \mathrm{m}^{3}$ untuk tahunan dan $1 \mu \mathrm{g} / \mathrm{m}^{3}$ untuk waktu 24 jam, sedangkan baku mutu $\mathrm{Pb}$ pada $\mathrm{PM}_{2.5}$ adalah $0.25 \mu \mathrm{g} / \mathrm{m}^{3}$ untuk tahunan dan $0.5 \mu \mathrm{g} / \mathrm{m}^{3}$ untuk $24 \mathrm{jam}$; As pada TSP $0.006 \mu \mathrm{g} / \mathrm{m}^{3}$ untuk tahunan dan $0.3 \mu \mathrm{g} / \mathrm{m}^{3}$ untuk $24 \mathrm{jam}$, As pada $\mathrm{PM}_{2.5} 0.00006 \mu \mathrm{g} / \mathrm{m}^{3}$ untuk tahunan dan $0.0125 \mu \mathrm{g} / \mathrm{m}^{3}$ untuk 24 jam; Cd pada TSP tahunan $0.005 \mu \mathrm{g} / \mathrm{m}^{3}$ dan $2 \mu \mathrm{g} / \mathrm{m}^{3}$ pada $24 \mathrm{jam}, \mathrm{Cd}$ pada $\mathrm{PM}_{2.5} 0.00005 \mu \mathrm{g} / \mathrm{m}^{3}$ pada tahunan dan $0.02 \mu \mathrm{g} / \mathrm{m}^{3}$ untuk $24 \mathrm{jam}$; $\mathrm{Hg}$ pada TSP tahunan $1 \mu \mathrm{g} / \mathrm{m}^{3}$ dan $0.5 \mu \mathrm{g} / \mathrm{m}^{3}$ untuk $24 \mathrm{jam}$, dan $\mathrm{Hg}$ pada $\mathrm{PM}_{2.5}$ tahunan $0.005 \mu \mathrm{g} / \mathrm{m}^{3}$ dan $0.01 \mu \mathrm{g} / \mathrm{m}^{3}$ untuk 24 jam. Cr pada TSP tahunan $0.01 \mu \mathrm{g} / \mathrm{m}^{3}$ dan $1.5 \mu \mathrm{g} / \mathrm{m}^{3}$ untuk 24 jam, dan $\mathrm{Cr}$ pada $\mathrm{PM}_{2.5}$ tahunan $0.0001 \mu \mathrm{g} / \mathrm{m}^{3}$ dan $0.005 \mu \mathrm{g} / \mathrm{m}^{3}$ untuk $24 \mathrm{jam}$; Mn pada TSP tahunan $0.15 \mu \mathrm{g} / \mathrm{m}^{3} \mathrm{dan} 2.5 \mu \mathrm{g} / \mathrm{m}^{3}$ untuk 24 jam, dan Mn pada $\mathrm{PM}_{2.5}$ tahunan $0.00015 \mu \mathrm{g} / \mathrm{m}^{3}$ dan $0.0078 \mu \mathrm{g} / \mathrm{m}^{3}$ untuk $24 \mathrm{jam}$; Ni pada TSP tahunan $0.02 \mu \mathrm{g} / \mathrm{m}^{3}$ dan $2 \mu \mathrm{g} / \mathrm{m}^{3}$ untuk 24 jam dan Ni pada $\mathrm{PM}_{2.5}$ tahunan $0.0002 \mu \mathrm{g} / \mathrm{m}^{3}$ dan $0.015 \mu \mathrm{g} / \mathrm{m}^{3}$ untuk $24 \mathrm{jam}$.
\end{abstract}

Kata Kunci: logam berat, udara ambien, revisi, baku mutu udara ambien, pengendalian pencemaran udara.

\begin{abstract}
Heavy metals contained in the ambient air particulate matter PM2.5 in particular can be harmful to humans due to PM2.5 size allows it to penetrate the deepest parts of the lungs and the heart and it cause a variety of health problems, such as acute respiratory infections, lung cancer pulmonary, cardiovascular disease and even death. Government Regulation, PP. 41/1999 on air pollution control already regulate the standard of heavy metals in ambient air but only limited to lead (Pb), while other hazardous metals such as arsenic (As), cadmium (Cd), mercury (Hg) , chromium (Cr), manganese (Mn), and nickel (Ni) has not regulated in the PP. Thus it necessary to study heavy metals in ambient air particulate matter PM2.5 as a scientific basis in order to revise Appendix of PP 41/1999. In addition, the value of the quality standards set out in the Regulation should be reviewed to see compliance with environmental or ambient air conditions at this time. The proposals presented in the framework of the revision of
\end{abstract}

\footnotetext{
${ }^{1}$ Pusat Sarana Pengendalian Dampak Lingkungan (PUSARPEDAL) Gedung 210 Kawasan Puspiptek Jl. Raya Puspiptek Serpong-Tangerang 15310, BANTEN, T/F:021-7560983, Email: ritaiim@yahoo.com

${ }^{2}$ PTNBR - Pusat Teknologi Nuklir Bahan dan Radiometri-Badan Tenaga Nuklir Nasional, J1 Tamansari No. 71 Bandung 40132 ,

telp.022-2503997, Fax.022-2504081;website:www.batan-bdg,go.id; E-mail:PTNBR@batan.go.id
} 
Appendix PP 41/1999 on air pollution control are parameters of heavy metals in airborne particulate size of TSP and PM2.5 standards, namely Pb in TSP tightened to $0.5 \mu \mathrm{g} / \mathrm{m} 3$ for annual and $1 \mu \mathrm{g} / \mathrm{m} 3$ for 24 hours, while the quality standard on Pb in PM2.5 $0.25 \mu \mathrm{g} / \mathrm{m} 3$ for annual and $0.5 \mu \mathrm{g} / \mathrm{m} 3$ for 24 hours; As in TSP $0.006 \mu \mathrm{g} / \mathrm{m} 3$ for annual and $0.3 \mu \mathrm{g} / \mathrm{m} 3$ for 24 hours, As in PM2 $.50 .00006 \mu \mathrm{g} / \mathrm{m} 3$ for annual and $0.0125 \mu \mathrm{g} / \mathrm{m} 3$ for 24 hours;Cd in TSP $0.005 \mu \mathrm{g} / \mathrm{m} 3$ for annual and $2 \mu \mathrm{g} / \mathrm{m} 3$ at 24 hours, Cd in PM2.5 0.00005 $\mu \mathrm{g} / \mathrm{m} 3$ for annual and $0.02 \mu \mathrm{g} /$ m3 for 24 hours; Hg in TSP $1 \mu \mathrm{g} / \mathrm{m} 3$ for anual and $0.5 \mu \mathrm{g} / \mathrm{m} 3$ for 24 hours, and Hg in PM2.5 $0.005 \mu \mathrm{g} / \mathrm{m} 3$ for annual and $0.01 \mu \mathrm{g} / \mathrm{m} 3$ for 24 hours; Cr in TSP $0.01 \mu \mathrm{g} / \mathrm{m} 3$ for annual and $1.5 \mu \mathrm{g} / \mathrm{m} 3$ for 24 hours, and Cr in in PM2.5 $0.0001 \mu \mathrm{g} / \mathrm{m} 3$ for annual and $0.005 \mu \mathrm{g} / \mathrm{m} 3$ for 24 hours; Mn TSP $0.15 \mu \mathrm{g} / \mathrm{m} 3$ for annual and $2.5 \mu \mathrm{g} / \mathrm{m} 3$ for 24 hours, and Mn in PM2.5 0.00015 $\mu \mathrm{g} / \mathrm{m} 3$ for annual and 0.0078 $\mu \mathrm{g} / \mathrm{m} 3$ for 24 hours; Ni in TSP $0.02 \mu \mathrm{g} / \mathrm{m} 3$ for annual and $2 \mu \mathrm{g} / \mathrm{m} 3$ for 24- hours and Ni in PM2.5 $0.0002 \mu \mathrm{g} / \mathrm{m} 3$ for annual and $0.015 \mu \mathrm{g} / \mathrm{m} 3$ for 24 hours.

Keywords: heavy metal, air ambient, revision, ambien air quality standard, air pollution control

\section{PENDAHULUAN}

Logam berat timbal $(\mathrm{Pb})$, arsen (As), kadmium $(\mathrm{Cd})$, merkuri $(\mathrm{Hg})$, kromium $(\mathrm{Cr})$, mangan (Mn), dan nikel (Ni) adalah beberapa logam berat yang menjadi pencemar di udara ambien yang umumnya berasal dari kegiatan industri dan pembakaran batubara. Meskipun kadarnya di atmosfer rendah, logam-logam tersebut berkontribusi pada deposisi dan penumpukan kandungan logam berat dalam tanah, sedimen dan organisme. Beberapa logam berat yang ada di lingkungan membentuk bioakumulasi dalam rantai makanan, sehingga menimbulkan dampak negatif terhadap kesehatan manusia dan lingkungan $[1,2]$.

Keterpaparan arsenik terkait dengan peningkatan risiko kanker kulit dan paruparu. Kadmium terkait dengan ginjal dan kerusakan tulang dan juga telah diidentifikasi potensial menyebabkan karsinogen pada manusia, kanker paru-paru, dan efek neuro - perilaku pada janin, bayi dan anak-anak, dan meningkatkan tekanan darah pada orang dewasa. Merkuri merupakan racun dalam bentuk unsur anorganik, tetapi perhatian utama terkait pada senyawa organik, khususnya methylmercury, karena senyawa ini terakumulasi dalam rantai makanan, misalnya pada ikan predator di danau dan laut hingga sampai ke manusia. Kromium bisa mengalami gangguan pernapasan dan alat pencernaan. Mangan pada dosis yang tinggi dapat mengakibatkan gangguan pada sistem saraf. Nikel disamping dikenal karsinogen, juga memiliki efek non-kanker lainnya, misalnya pada sistem endokrin $[1,2]$.

Polusi udara yang disebabkan oleh paparan logam berat sangat berpengaruh untuk jangka panjang, disamping itu polutan logam berat ini tahan di udara dan dapat berpindah-pindah sampai ke daerah yang paling terpencil, karena biasanya polutan logam berat terkandung dalam debu melayang di udara ambien dan apabila terhirup oleh manusia melalui saluran pernafasan menembus sampai ke bagian dalam paru-paru ke pembuluh darah hingga ke jantung. Logam berat tersebut terdapat didalam partikulat dalam ukuran $\mathrm{PM}_{2.5}$ [2].

Di dalam Lampiran Peraturan Pemerintah No.41 Tahun 1999 tentang Pengendalian Pencemaran Udara terdapat parameter logam berat timbal $(\mathrm{Pb})$ yang telah diatur baku mutunya, dengan nilai baku mutu $\mathrm{Pb}$ tahunan di udara ambien adalah $1 \mu \mathrm{g} / \mathrm{m}^{3}$, dan $2 \mu \mathrm{g} / \mathrm{m}^{3}$ untuk pengukuran 24 jam. Baku mutu tersebut dalam bentuk TSP yang ukuran partikulatnya $<100 \mu \mathrm{m}^{3}$. 
Beberapa penelitian menunjukkan bahwa $\mathrm{Pb}$ yang terserap oleh anak walaupun dalam jumlah kecil dapat menyebabkan gangguan pada fase awal pertumbuhan fisik dan mental, yang kemudian berakibat pada fungsi kecerdasan dan kemampuan berfikir. Kandungan $\mathrm{Pb}$ dalam darah berkorelasi dengan tingkat kecerdasan, semakin tinggi kadar $\mathrm{Pb}$ dalam darah, semakin rendah poin IQnya4.

Data mengenai kandungan logam berat timbal $\mathrm{Pb})$ diudara ambien di Indonesia sangat terbatas. Kemungkinan data tersebut ada dan tersimpan di lembaga masing-masing yang memantaunya. Pemerintah dalam hal ini perlu menjalin kerjasama, koordinasi, dan sinergi kegiatan agar hasil yang diperoleh lebih efektif dan efisien.

Beberapa negara seperti Malaysia, Thailand, Filipina, Bangladesh, Kamboja, Korea, Nepal, Hongkong, China, India, Swis, Inggris, Amerika, disamping telah memiliki baku mutu logam berat $\mathrm{Pb}$ di masing-masing negaranya juga telah mengatur baku mutu logam berat lainnya. Australia, selain mengatur parameter $\mathrm{Pb}$, juga telah mencantumkan baku mutu $\mathrm{Cd}$, As, Mn, Hg, V. Demikian juga Vietnam, selain $\mathrm{Pb}$ juga telah mengatur baku mutu $\mathrm{Cd}, \mathrm{Mn}$, $\mathrm{Hg}$, As, Ni, Cr6+ . Washington DC, selain Pb, telah memiliki bakumutu logam berat $\mathrm{Cd}$, As, Cr di udara ambien.6

Jika dilihat baku mutu $\mathrm{Pb}$ pada PP 41/1999 tentang pengendalian pencemaran udara, bagaimana nilai baku mutu tersebut apakah sudah cukup atau terlalu longgar? jika dibandingkan dengan melihat kondisi kadar polutan $\mathrm{Pb}$ di udara ambien dengan tingkat kesehatan masyarakat di negara kita?, sedangkan di negara lain nilainya semakin ketat $[8,9]$.

Hal lain yang harus dilakukan setelah baku mutu ditetapkan adalah peninjauan angka/ nilai baku mutu tersebut apakah masih relevan dengan kondisi lingkungan atau udara ambien kita pada saat ini. Beberapa negara seperti India, Vietnam, Bangladesh, Nepal, Republik of Korea (Seoul), Hongkong, Swis, Inggris, dan organisasi WHO telah menetapkan baku mutu logam berat $\mathrm{Pb}$ tahunan $0.5 \mu \mathrm{g} /$ $\mathrm{m}^{3}$, dan $1 \mu \mathrm{g} / \mathrm{m}^{3}$ untuk pengukuran 24 jam. Sementara negara kita masih menetapkan baku mutu $\mathrm{Pb}$ tahunan $1 \mu \mathrm{g} / \mathrm{m}^{3}$, dan $2 \mu \mathrm{g} /$ $\mathrm{m}^{3}$ untuk pengukuran 24 jam. Bukannya kita mau ikut-ikutan memperketat aturan kita, namun yang perlu dilakukan adalah mengkaji baku mutu tersebut apakah masih relevan dan bagaimana tingkat kesehatan manusia Indonesia terhadap pengaruh timbal di udara ambien, terutama untuk logam yang berada pada ukuran $\mathrm{PM}_{2.5}$.

Pada makalah ini dilakukan kajian mengenai nilai baku mutu logam berat dengan melihat perbandingannya kadar logam berat di negara kita dan nilai baku mutu logam berat di beberapa negara sebagai pembanding. Lingkup parameter yang dikaji adalah logam berat timbal $(\mathrm{Pb})$, arsen (As), kadmium (Cd), merkuri $(\mathrm{Hg})$, kromium $(\mathrm{Cr})$, mangan $(\mathrm{Mn})$, dan nikel (Ni) di udara ambien. Logam berat yang dikaji khususnya logam berat didalam partikulat $\mathrm{PM}_{2.5}$. Kajian ini diharapkan dapat digunakan sebagai bahan masukan dalam revisi PP 41/1999 tentang pengendalian pencemaran udara, khususnya untuk parameter logam berat. 


\section{METODOLOGI}

Metode yang digunakan dalam kajian baku mutu ini adalah metode kuantitatif dan kualitatif, sebagai berikut:

- Kajian studi literatur diantaranya: studi literatur mengenai dampak logam berat terhadap kesehatan manusia dan studi literatur mengenai baku mutu logam berat di udara ambien di beberapa negara sebagai perbandingan.

- Kajian data yang diperoleh dari hasil kajian logam berat di udara ambien khususnya logam berat dalam ukuran partikulat $\mathrm{PM}_{2.5}$, berdasarkan laporan kegiatan Pusarpedal kerjasama dengan PTNBR-Batan Bandung, sejak th.20082012 di beberapa lokasi dan waktu yang berbeda-beda menggunakan alat Gent Staked Filter Unit Sampler dan analisis menggunakan teknik nuklir seperti metode AAN (analisis aktivasi neutron), telah mencapai \pm 400 buah sampel, dan \pm 30 unsur diantaranya $\mathrm{Na}, \mathrm{Al}, \mathrm{Br}, \mathrm{V}, \mathrm{Mn}$, $\mathrm{Mg}, \mathrm{I}, \mathrm{Cl}, \mathrm{Cr}, \mathrm{Fe}, \mathrm{Zn}, \mathrm{Sc}, \mathrm{Sb}, \mathrm{Co}, \mathrm{La}$, $\mathrm{Sm}, \mathrm{Nd}, \mathrm{K}, \mathrm{Ca}, \mathrm{Ti}, \mathrm{Pb}, \mathrm{Cu}, \mathrm{As}, \mathrm{Ce}, \mathrm{Th}$, $\mathrm{Hf}, \mathrm{Cs}, \mathrm{Se}, \mathrm{Hg}$, dan $\mathrm{Rb}$ dan dengan alat PIXE (Proton Induce X-ray Emission) dapat menganalisis unsur diantaranya $\mathrm{Al}, \mathrm{As}, \mathrm{Ba}, \mathrm{Br}, \mathrm{Ca}, \mathrm{Cl}, \mathrm{Co}, \mathrm{Cr}, \mathrm{Cu}, \mathrm{Fe}$, $\mathrm{Hg}, \mathrm{I}, \mathrm{K}, \mathrm{Mg}, \mathrm{Mn}, \mathrm{Na}, \mathrm{Ni}, \mathrm{P}, \mathrm{Pb}, \mathrm{S}, \mathrm{Sc}$, Si, Se, Sr, Ti, V dan Zn.

- Lingkup parameter yang dikaji adalah: timbal $(\mathrm{Pb})$, kromium $(\mathrm{Cr})$, mangan $(\mathrm{Mn})$, nikel (Ni), arsen (As), merkuri $(\mathrm{Hg})$, dan kadmium (Cd) di TSP berdasarkan literatur dan parameter logam berat tersebut didalam $\mathrm{PM}_{2.5}$.

\section{HASIL DAN PEMBAHASAN}

Logam berat timbal (Pb), baku mutu $\mathrm{Pb}$ yang terdapat pada lampiran PP 41/1999 tentang pengendalian pencemaran udara dengan nilai baku mutu $\mathrm{Pb}$ adalah $2 \mu \mathrm{g} / \mathrm{m}^{3}$ untuk waktu pengukuran 24 jam dan $1 \mu \mathrm{g} / \mathrm{m}^{3}$ untuk waktu pengukuran 1 tahun. Berdasarkan tinjauan baku mutu logam berat $\mathrm{Pb}$ di udara ambien di beberapa negara yang disajikan pada Tabel 1. Pada umumnya baku mutu $\mathrm{Pb}$ dibeberapa negara untuk pengukuran 24 jam berkisar antara $0.75-2 \mu \mathrm{g} / \mathrm{m}^{3}$ dan $0.25-1 \mu \mathrm{g} / \mathrm{m}^{3}$ untuk pengukuran 1 tahun.

Baku mutu $\mathrm{Pb}$ di India dibagi atas 3 (tiga) area yaitu; industrial area, residential, rural and other, serta sensitive area, demikian juga dengan Cina terdiri dari Grade 1, 2, dan 3. Kemungkinan ini dapat diterapkan untuk negara yang tata ruangnya sudah teratur. Jika dibandingkan dengan data yang ada di beberapa daerah di Indonesia yang dipantau melalui kerjasama Pusarpedal-KLH dengan Pusat Tenaga Nuklir Bahan dan Radiometri (PTNBR) Batan Bandung dari 755 jumlah data diperoleh konsentrasi logam berat $\mathrm{Pb}$ pada ukuran $\mathrm{PM}_{2.5}$ berada pada kisaran 0.002-37.3 $\mu \mathrm{g} / \mathrm{m}^{3}$, dengan rerata $0.5 \mu \mathrm{g} / \mathrm{m}^{3}$ dengan standar deviasi 2778. Tingginya standar deviasi karena lokasi pengambilan contoh uji yang beragam, mulai dari pemukiman, perkantoran, daerah yang dekat kegiatan pembakaran aki bekas, dan daerah yang dekat dengan industri daur ulang aki bekas. Daerah yang dipantau terdiri dari Jakarta, Tangerang dan sekitarnya, Bogor, Bandung, Yogyakarta, Semarang, Surabaya, Riau-Pekanbaru, Makassar, Palangkaraya, dan Denpasar-Bali. Dengan kondisi topografi 
Tabel 1. Baku Mutu Logam Berat Pb di Udara Ambien di Beberapa Negara

\begin{tabular}{|c|c|c|c|c|c|c|}
\hline \multirow{2}{*}{ No } & \multirow{2}{*}{ Negara } & \multicolumn{5}{|c|}{ Waktu Pengukuran $\mu \mathrm{g} / \mathrm{m}^{3}$} \\
\hline & & 1 tahun & $24 \mathrm{jam}$ & 3 bulan & 1 bulan & $1 \mathrm{jam}$ \\
\hline 1 & Indonesia (PP41/1999) & 1 & 2 & & & \\
\hline 2 & China Grade 1, 2, 3 & 1 & & & & \\
\hline 3 & Philipphines & 1 & & 1.5 & & \\
\hline 4 & India $=$ Industrial Area & 1 & 1.5 & & & \\
\hline 5 & India $=$ Residential, rural and other & 0.75 & 1 & & & \\
\hline 6 & India $=$ Sensitive area & 0.5 & 0.75 & & & \\
\hline 7 & India 1 dan 2 & 0.5 & 1 & & & \\
\hline 8 & Vietnam & 0.5 & 1.5 & & & \\
\hline 9 & Ontorio (OAQC/TCEQ) & 0.5 & 2 & & & \\
\hline 10 & Bangladesh & 0.5 & & & & \\
\hline 11 & Nepal & 0.5 & & & & \\
\hline 12 & Republic of Korea & 0.5 & & & & \\
\hline 13 & Republic of Korea (Seoul) & 0.5 & & 1.0 & & \\
\hline 14 & Hongkong (HKSAR's AQO) & 0.5 & & 1.5 & & \\
\hline 15 & Switzerland & 0.5 & & & & \\
\hline 16 & Australia & 0.5 & & & & \\
\hline 17 & European commission (QS) & 0.5 & & & & \\
\hline 18 & EU 2005, 2012 & 0.5 & & & & \\
\hline 19 & UK-2004 & 0.5 & & & & \\
\hline 20 & UK-2008 & 0.25 & & & & \\
\hline 21 & WHO AQGs 2000 & 0.5 & & & & \\
\hline 22 & New Zealand 1994 & & & $0.5-1$ & & \\
\hline 23 & New Zealand 1999 & & & 0.2 & & \\
\hline 24 & WHO (AAQG) & $0.5-1$ & & & & \\
\hline 25 & WHO 2005 & & & 1.5 & & \\
\hline 26 & US EPA NAAQSC & & & 1.5 & & \\
\hline 27 & Malaysia (MAAQS) & & & 1.5 & & \\
\hline 28 & HK AQO & & & 1.5 & & \\
\hline 29 & United States -EPA (NAAQS) & & & 0.15 & & \\
\hline 30 & Canada & & & & & 1.5 \\
\hline 31 & Thailand & & & & 1.5 & \\
\hline
\end{tabular}

yang berbeda-beda, dan situasi dan kondisi yang berbeda juga (situasi normal, kebakaran hutan, peleburan aki bekas, transportasi). Ada usulan untuk membagi-bagi area seperti di India dan Cina, namun kendalanya di negara kita kondisi tata ruangnya belum teratur, hal ini dibuktikan di sela-sela industri masih ada pemukiman.

Berdasarkan pengujian Komisi Pembebasan Bensin Bertimbal (KPBB) yang didukung oleh
Blacksmith Institute melakukan penelitian pada pemaparan timbal dari kegiatan daur ulang aki bekas di Jakarta dan sekitarnya. Dari kegiatan tersebut menemukan 71 lokasi peleburan timah dan tempat penampungan aki bekas di Jakarta dan wilayah sekitarnya. Maka diketahui bahwa kebanyakan lokasi yang berada disekitar tempat peleburan memiliki kandungan timbal dalam tanah melebihi standar WHO (400 ppm). Nilai rata- 
rata dari 1300 sampel tanah menunjukkan bahwa konsentrasi timbal dalam tanah adalah 4179.9 ppm, dengan kisaran minimum 12,5 dan maksimum 252600 ppm4. Data dari Pusarpedal-KLH kerjasama dengan Batan, diperoleh $\mathrm{Pb}$ di udara ambien di CinangkaBogor dengan nilai berkisar 0.12-15.46 $\mu \mathrm{g} /$ $\mathrm{m} 3$ dengan rerata $6.12 \mu \mathrm{g} / \mathrm{m} 3$ dan $\mathrm{Pb}$ di daerah Curug dengan nilai berkisar 0.13-0.47 $\mu \mathrm{g} / \mathrm{m} 3$ dengan rerata $0.29 \mu \mathrm{g} / \mathrm{m} 3$.

Sejalan dengan kegiatan ini KPBB dan Blacksmith Institute juga melakukan pengukuran Blood Lead Level-BLL) terhadap 400 sampel siswa sekolah dasar di Jakarta dan sekitarnya. Sampel darah dianalisa menggunakan LeadCare 2 portable anlyzer (ESA Laboratories.Chelmsford, MA,USA). Sampai Oktober 2010 kegiatan tersebut sudah dilaksanakan di 40 sampel di Desa Cinangka, Kabupaten Bogor dan 40 sampel di Kampung Curug-Kabupaten Tangerang-Banten. Kedua daerah tersebut berada di daerah peleburan aki bekas. Berdasarkan penelitian, rata-rata kadar $\mathrm{Pb}$ dalam darah (BLL) anak-anak CinangkaBogor adalah $36.62 \mu \mathrm{g} / \mathrm{dl}$ dengan nilai minimum $16.20 \mu \mathrm{g} / \mathrm{dl}$ dan nilai maksimum adalah high (berarti lebih dari $60 \mu \mathrm{g} / \mathrm{dl}$ ). Rerata kadar $\mathrm{Pb}$ anak-anak di kampung Curug adalah $24.18 \mu \mathrm{g} / \mathrm{dl}$, dengan nilai minimum $12.10 \mu \mathrm{g} / \mathrm{dl}$ dan nilai maksimum $47.80 \mu \mathrm{g} /$ dl. Siswa sekolah yang berada di kedua area tersebut (Cinangka dan Curug) 100\% memiliki kandungan BLL diatas batas toleransi yang ditetapkan WHO yaitu sebesar $10 \mu \mathrm{g} / \mathrm{dl} .4$

Kandungan $\mathrm{Pb}$ dalam darah berkorelasi dengan tingkat kecerdasan, semakin tinggi kadar $\mathrm{Pb}$ dalam darah, semakin rendah poin IQnya4. Menurunnya tingkat kesehatan masyarakat sebagai dampak dari pencemaran udara. Hal ini kemungkinan disebabkan karena longgarnya baku mutu salah satunya Pb yang terdapat didalam PP 41/1999 tentang pengendalian pencemaran udara di negara kita ini [4].

Maka dari hasil kajian ini dapat disimpulkan bahwa baku mutu Pb menurut PP41/1999 yang berada pada ukuran TSP $(<100 \mu \mathrm{m})$ untuk waktu pengukuran 24 jam dengan nilai $2 \mu \mathrm{g} / \mathrm{m}^{3}$ terlalu longgar jika dibandingkan dengan baku mutu beberapa negara, hal ini didukung dengan kondisi kesehatan masyarakat Indonesia yang semakin menurun, terutama jika dilihat dari kandungan timbal di darah anak-anak yang berada diatas baku mutu menurut WHO yaitu $10 \mu \mathrm{g} / \mathrm{dl}$. Dari hasil kajian Pusarpedal-Batan diusulkan untuk dimasukkan baku mutu $\mathrm{Pb}$ yang berada pada ukuran partikulat $\mathrm{PM}_{2.5}$ karena mengingat tingkat bahayanya terhadap manusia sangat berbahaya dibandingkan dengan $\mathrm{Pb}$ pada ukuran TSP yang angkanya tinggi namun tidak spesifik menunjukkan bahaya terhadap kesehatan masyarakat. Angka $\mathrm{Pb}$ yang ada diperoleh dari hasil pemantauan dan kajian $\mathrm{Pb}$ di udara ambien pada ukuran $\mathrm{PM}_{2.5}$ adalah $0.002-37.3 \mu \mathrm{g} / \mathrm{m}^{3}$, dengan rerata $0.5 \mu \mathrm{g} / \mathrm{m}^{3}$ maka baku mutu yang diusulkan untuk $\mathrm{Pb}$ pada ukuran $\mathrm{PM}_{2.5}$ adalah $0.5 \mu \mathrm{g} /$ $\mathrm{m}^{3}$ untuk pengukuran 24 jam dan $0.25 \mu \mathrm{g} /$ $\mathrm{m}^{3}$ untuk waktu pengukuran 1 tahun. Untuk ukuran $\mathrm{Pb}$ pada TSP diusulkan minimal sama dengan negara-negara lain yaitu $1 \mu \mathrm{g} / \mathrm{m}^{3}$ untuk pengukuran 24 jam dan $0.5 \mu \mathrm{g} / \mathrm{m}^{3}$ untuk pengukuran 1 tahun $[5,10]$.

Logam berat arsenik (As), berdasarkan literatur dapat meningkatan risiko kanker kulit dan paru-paru, maka jenis logam ini juga perlu diatur di negara kita. Berdasarkan 326 jumlah 
Tabel 2. Baku Mutu Logam Berat As (Arsen) di Udara Ambien di beberapa negara.

\begin{tabular}{llccc}
\hline \multirow{2}{*}{ No } & Negara & \multicolumn{3}{c}{ Waktu Pengukuran dalam satuan $\left(\mu \mathrm{g} / \mathrm{m}^{3}\right)$} \\
\cline { 3 - 4 } & & 1 tahun & 24 jam & 1 jam \\
\hline 1 & Vietnam & 0.005 & 0.03 \\
2 & European Commision (AQS) & 0.006 & \\
3 & AQS-Environment-European & 0.006 & \\
4 & India 1 & 0.006 & \\
5 & India 2 & 0.006 & & \\
6 & OAQC/TCEQ & 0.5 & 0.3 & \\
\hline
\end{tabular}

data hasil kajian Pusarpedal-Batan diperoleh nilai As yang terdapat di udara ambien pada partikulat $\mathrm{PM}_{2.5}$ berkisar $0.000007-0.2734$ $\mu \mathrm{g} / \mathrm{m}^{3}$ atau $0.007-273.4 \mathrm{ng} / \mathrm{m}^{3}$ dengan rerata $0.0125 \mu \mathrm{g} / \mathrm{m}^{3}$ atau $12.5 \mathrm{ng} / \mathrm{m}^{3}$, standar deviasi 23.1, kondisi lokasi sampling sama dengan $\mathrm{Pb}$.

Untuk parameter As belum tercantum pada PP41/1999, beberapa negara sudah mempunyai baku mutu As di udara ambien seperti yang disajikan pada Tabel 2 . Mengingat bahayanya terhadap kesehatan maka diusulkan parameter As untuk dimasukkan kedalam PP41/1999 dengan nilai As yang untuk ukuran TSP adalah 0.3 $\mu \mathrm{g} / \mathrm{m}^{3}$ untuk waktu pengukuran 24 jam dan $0.006 \mu \mathrm{g} / \mathrm{m}^{3}$ untuk pengukuran tahunan. baku mutu As pada $\mathrm{PM}_{2.5}$ yang diusulkan $0.00006 \mu \mathrm{g} / \mathrm{m}^{3}$ untuk tahunan dan 0.0125 $\mu \mathrm{g} / \mathrm{m}^{3}$ untuk waktu pengukuran 24 jam.
Logam berat kadmium (Cd), dapat merusak ginjal dan kerusakan tulang dan juga telah diidentifikasi potensial menyebabkan karsinogen pada manusia, kanker paru-paru, dan efek neuro, serta meningkatkan tekanan darah pada orang dewasa. Parameter Cd di udara termasuk sulituntuk diukur, sama halnya dengan $\mathrm{Cd}$ di air, mungkin karena jumlahya sedikit dialam, namun tingkat bahayanya cukup tinggi. Maka untuk menganalisis $\mathrm{Cd}$ di udara ambien perlu teknik yang khusus dan selektif. Dengan menggunakan teknologi nuklir ini maka diharapkan dengan kerjasama Pusarpedal-Batan ini dapat diperoleh data $\mathrm{Cd}$ di udara ambien. Untuk parameter $\mathrm{Cd}$ di beberapa negara yang telah mengaturnya ke dalam baku mutu Cd di udara ambien disajikan pada Tabel 3.

Tabel 3. Baku Mutu Logam Berat Cd (Kadmium) di Udara Ambien

\begin{tabular}{llcccc}
\hline \multirow{2}{*}{ No Negara/organisasi } & \multicolumn{3}{c}{ Waktu Pengukuran dalam satuan $\left(\mu \mathrm{g} / \mathrm{m}^{3}\right)$} \\
\cline { 2 - 5 } & & 1 tahun & 24 jam & $8 \mathrm{jam}$ & $1 \mathrm{jam}$ \\
\hline 1 & WHO & 0.005 & & & \\
2 & European commission (QS) & 0.005 & & & \\
3 & Australian Fine Particles Study & 0.005 & & & \\
4 & AQS-Environment-European & 0.005 & & & \\
5 & WHO AQGs 2000 & 0.005 & & & 0.2 \\
6 & Vietnam & 0.005 & & 0.2 & 0.4 \\
7 & OAQC/TCEQ & 0.05 & 2 & & \\
\hline
\end{tabular}


Dari data yang ada di beberapa negara untuk parameter $\mathrm{Cd}$ di udara ambien diusulkan 2 $\mu \mathrm{g} / \mathrm{m}^{3}$ untuk pengukuran 24 jam dan 0.005 $\mu \mathrm{g} / \mathrm{m}^{3}$ untuk pengukuran tahunan, sedangkan untuk $\mathrm{Cd}$ di udara ambien pada ukuran $\mathrm{PM}_{2.5}$ diusulkan nilainya $1 / 100$ kali dari TSP mengingat TSP berada pada ukuran $100 \mu \mathrm{m}$, sedangkan $\mathrm{PM}_{2.5}$ berada pada ukuran $<2.5$ $\mu \mathrm{m}$, maka nilai yang diusulkan yaitu 0.02 $\mu \mathrm{g} / \mathrm{m}^{3}$ untuk pengukuran 24 jam dan 0.00005 $\mu \mathrm{g} / \mathrm{m}^{3}$ untuk pengukuran tahunan.

Merkuri (Hg), walaupun Hg berbahaya dalam bentuk methylmerkuri, namun keberadaan logam $\mathrm{Hg}$ diudara ambien perlu diwaspadai, karena $\mathrm{Hg}$ bersifat akumulatif sehingga dapat menjadi bentuk organik yang lebih berbahaya dapat merusak jaringan syaraf. Pengalaman negara Jepang yang harus membayar mahal akibat keracunan methylmerkuri telah menjadi pelajaran bagi negara-negara lain. Beberapa negara telah mengatur baku mutu $\mathrm{Hg}$ di udara ambien seperti disajikan pada Tabel 4 .

Hasil kajian $\mathrm{Hg}$ di udara ambien atas kerjasama Pusarpedal-Batan dengan waktu pengukuran 24 jam pada ukuran $\mathrm{PM}_{2.5}$ dari 132 jumlah sampel diperoleh hasil $\mathrm{Hg}$ di udara ambien pada rentang $2.162-44.7 \mathrm{ng} / \mathrm{m}^{3}$ atau 0.002162 $0.0447 \mu \mathrm{g} / \mathrm{m}^{3}$ dengan rerata $10.3 \mathrm{ng} / \mathrm{m}^{3}$ atau $0.0103 \mu \mathrm{g} / \mathrm{m}^{3}$ dan standar deviasi 8. Maka diusulkan untuk parameter $\mathrm{Hg}$ dimasukkan kedalam PP41/1999 jika dalam TSP diusulkan angkanya sama dengan beberapa negara yang telah mengaturnya yaitu $1 \mu \mathrm{g} / \mathrm{m}^{3}$ untuk tahunan dan $0,5 \mu \mathrm{g} / \mathrm{m}^{3}$ untuk waktu pengukuran 24 jam, sedangkan untuk $\mathrm{Hg}$ yang berada dalam $\mathrm{PM}_{2.5}$ diusulkan angkanya jauh lebih kecil yaitu $0.01 \mu \mathrm{g} / \mathrm{m}^{3}$ untuk waktu pengukuran 24 jam dan $0.005 \mu \mathrm{g} / \mathrm{m}^{3}$ untuk waktu pengukuran 1 tahun.

Kromiun (Cr), efek dari Cr terhadap kesehatan yakni bisa mengalami gangguan pernapasan dan juga mengganggu alat pencernaan. Chromium (VI) dikenal dapat menyebabkan berbagai gangguan kesehatan diantaranya: ruam kulit, gangguan perut, permasalahan berhubungan dengan pernapasan, sistem kekebalan tubuh yang melemah, ginjal dan kerusakan hati, masalah keturunan, kanker paru-paru, bahkan kematian. Ontario Ministry of the Environment Ambient Air Quality Criteria /Texas Commission on Environment Quality (OAQC/TCEQ) mengatur baku mutu tahunan Cr tahunan $0.01 \mu \mathrm{g} / \mathrm{m}^{3}$ dan $1.5 \mu \mathrm{g} / \mathrm{m}^{3}$ untuk waktu pengukuran 24 jam.

Berdasarkan data Pusarpedal-Batan diperoleh kisaran $\mathrm{Cr}$ di udara ambien pada $\mathrm{PM}_{2.5}$ adalah $0.094-21.5 \mathrm{ng} / \mathrm{m}^{3}$ atau $0.000094-0.0215 \mu \mathrm{g} /$ $\mathrm{m}^{3}$ dengan rerata $3.2 \mathrm{ng} / \mathrm{m}^{3}$ atau $0.0032 \mu \mathrm{g} /$ $\mathrm{m} 3$ standar deviasi 2.8, waktu pengukuran 24

Tabel 4. Baku Mutu Logam Berat Hg (Merkuri) di Udara Ambien di beberapa negara

\begin{tabular}{llcc}
\hline \multirow{2}{*}{ No Negara/sumber lainnya } & \multicolumn{2}{c}{ Waktu Pengukuran $\left(\mu \mathrm{g} / \mathrm{m}^{3}\right)$} \\
\cline { 3 - 4 } & & 1 tahun & $24 \mathrm{jam}$ \\
\hline 1 & WHO, WHO AQGs 2000 & 1 & 2 \\
2 & OAQC/TCEQ & 1 & \\
3 & AFP, dalam Jurnal Atmosphere & 1 & \\
4 & AQM second Edition & & 0.3 \\
5 & Vietnam & & \\
\hline
\end{tabular}


jam. Maka diusulkan untuk PP41/1999 baku mutu Cr pada TSP adalah $0.01 \mu \mathrm{g} / \mathrm{m} 3$ untuk waktu 1 tahun dan $1.5 \mu \mathrm{g} / \mathrm{m} 3$ untuk waktu pengukuran 24 jam. Sedangkan untuk Cr pada ukuran PM2.5 diusulkan $0.0001 \mu \mathrm{g} / \mathrm{m} 3$ untuk waktu pengukuran 1 tahun dan $0.005 \mu \mathrm{g} / \mathrm{m} 3$ untuk waktu pengukuran 24 jam.

Mangan (Mn), Penanganan terpapar dengan debu mangan, uap dan senyawanya tidak boleh melebihi angka 5 ppm bahkan untuk periode yang sangat pendek karena tingkat toksisitas unsurnya. Mangan yang secara alami dapat ditemukan di air, tanah, dan udara. Mangan adalah zat nutrisi esensial bagi manusia dan hewan. Pajanan kronik mangan pada dosis yang tinggi dapat mengakibatkan gangguan pada sistem saraf. Target utama akibat toksisitas mangan adalah sistem saraf. Gejalagejala yang timbul adalah alergi, peningkatan tonus otot, tremor, gangguan mental, dan bahkan kematian. Beberapa negara telah mengatur Mn seperti yang disajikan pada Tabel 5.

Hasil pemantauan Pusarpedal dengan Batan dengan jumlah data 757 diperoleh kisaran Mn di udara ambien pada ukuran $\mathrm{PM}_{2.5}$ berkisar antara $0.025-255.4 \mathrm{ng} / \mathrm{m}^{3}$ atau 0.000025 $0.2554 \mu \mathrm{g} / \mathrm{m}^{3}$ rerata $7.8 \mathrm{ng} / \mathrm{m}^{3}$ atau $0.0078 \mu \mathrm{g} /$ $\mathrm{m}^{3}$ dan standar deviasi 12.3. Maka untuk baku mutu logam berat di udara ambien dalam rangka revisi PP41/1999 diusulkan baku mutu Mn dalam TSP dengan nilai $0.15 \mu \mathrm{g} /$ $\mathrm{m}^{3}$ untuk pengukuran 1 tahun dan $2.5 \mu \mathrm{g} / \mathrm{m}^{3}$ untuk pengukuran 24 jam. Dan untuk Mn pada PM2.5 diusulkan angka $0.0078 \mu \mathrm{g} / \mathrm{m}^{3}$ untuk waktu pengukuran $24 \mathrm{jam}$ dan $0.00015 \mu \mathrm{g} / \mathrm{m}^{3}$ untuk tahunan.

Nikel (Ni), digunakan secara besar-besaran untuk pembuatan baja tahan karat dan alloy lain yang bersifat tahan korosi. Nikel juga digunakan dalam keramik, pembuatan magnet Alnico dan baterai penyimpanan Edison. Nikel dan senyawanya tidak memiliki karakteristik bau atau rasa. Nikel terdapat di udara, menetap di tanah atau dikeluarkan dari udara dalam hujan. Sumber utama nikel adalah asap tembakau, knalpot mobil, pupuk, superfosfat, pengolahan makanan, dihidrogenasi lemak-minyak, limbah industri,peralatan masak stainless steel, pengujian perangkat nuklir, baking powder, pembakaran bahan bakar minyak, perawatan gigi dan jembatan. Efek yang ditimbulkan logam nikel adalah serangan asma, bronkitis kronis, sakit kepala, pusing, sesak napas, muntah, nyeri dada, batuk,

Tabel 5. Baku Mutu Logam Berat Mn (Mangan) di Udara Ambien di Beberapa Nagera

\begin{tabular}{llccr}
\hline \multirow{2}{*}{ No Negara/Sumber } & \multicolumn{3}{c}{ Baku Mutu dalam satuan $\left(\mu \mathrm{g} / \mathrm{m}^{3}\right)$} \\
\cline { 2 - 4 } & & 1 tahun & 24 jam & 1 jam \\
\hline 1 & OAQC/TCEQ & 0.015 & 2.5 & \\
4 & Hope valley, DEC,(AQM in Kwinana) & 0.02 & & \\
5 & AQM second Edition $^{2}$ & 0.15 & & \\
3 & WHO $^{4}$ & 0.15 & & \\
7 & WHO AQGs 2000 $^{6}$ & 0.15 & & \\
2 & WHO $^{3}$ & 0.15 & 0.018 & 10 \\
6 & Vietnam $^{22}$ & 0.15 & 8 & 10 \\
\hline
\end{tabular}


Tabel 6. Baku Mutu Logam Berat Ni (Nikel) di Udara Ambien di Beberapa Negara

\begin{tabular}{llcc}
\hline \multirow{2}{*}{ No } & Standar/Negara & \multicolumn{2}{c}{ Waktu Pengukuran dalam satuan $\left(\mu \mathrm{g} / \mathrm{m}^{3}\right)$} \\
\cline { 3 - 4 } & & 1 tahun & 24 jam \\
\hline 1 & European Commision (AQS) atau AQS-Environment-European & 0.02 & \\
2 & India 1 dan 2 & 0.02 & 2 \\
3 & OAQC/TCEQ & 0.015 & 1 \\
4 & Vietnam & & \\
\hline
\end{tabular}

sesak napas, kejang, bahkan kematian. Nikel berupa logam berwarna perak dalam bentuk berbagai mineral. Ni diproduksi dari biji Nickel, peleburan/daur ulang besi, terutama digunakan dalam berbagai macam baja dan suasa serta elektroplating. Salah satu sumber terbesar Ni terbesar di atmosphere berasal dari hasil pembakaran BBM, pertambangan, penyulingan minyak, incenerator. Dampak terhadap kesehatan Ni dan senyawanya merupakan bahan karsinogenik. Inhalasi debu yang mengandung Ni-Sulfide mengakibatkan kematian karena kanker pada paru-paru dan rongga hidung, dan kanker pita suara. Beberapa negara yang telah mengatur $\mathrm{Ni}$ disajikan pada Tabel 6.

Berdasarkan 545 jumlah data hasil pemantauan Pusarpedal-Batan diperoleh Ni di udara ambien pada ukuran $\mathrm{PM}_{2.5}$ berkisar $0.213-13.1 \mathrm{ng} / \mathrm{m}^{3}$ atau $0.000213-0.0131 \mu \mathrm{g} / \mathrm{m}^{3}$ dengan rerata $1.5 \mathrm{ng} / \mathrm{m}^{3}$ atau $0.015 \mu \mathrm{g} / \mathrm{m}^{3}$ standar deviasi 0.9. Usulan Ni pada revisi PP41/1999 untuk ukuran TSP Ni tahunan adalah $0.02 \mu \mathrm{g} / \mathrm{m}^{3}$ dan untuk pengukuran 24 jam adalah $2 \mu \mathrm{g} / \mathrm{m}^{3}$. Disamping itu usulan Ni pada PM2.5 adalah $0.0002 \mu \mathrm{g} / \mathrm{m}^{3}$ untuk pengukuran 1 tahun dan $0.015 \mu \mathrm{g} / \mathrm{m}^{3}$ untuk waktu pengukuran $24 \mathrm{jam}$.

\section{SIMPULAN}

Berdasarkan data bakumu logam berat dari beberapa negara dan data yang dipantau oleh
Pusarpedal bekerjasama dengan PTNBR BATAN Bandung, maka diusulkan beberapa parameter untuk dimasukkan ke dalam Lampiran PP 41/1999 sebagai baku mutu logam berat di udara ambien, parameter yang diusulkan adalah Kadmium (Cd), Arsen (As), Merkuri (Hg), Kromium (Cr), Mangan (Mn), dan Nikel (Ni). Dan waktu pengukuran yang diusulkan adalah 1 tahun dan 24 jam. Untuk parameter logam berat timbal $(\mathrm{Pb})$ diusulkan diperketat, namun harus melalui kajian lebih lanjut. Ada 2 (dua) ukuran partikulat yang diusulkan yaitu logam berat pada TSP seperti yang tercantum pada PP41/1999 dan logam berat pada ukuran $<2.5 \mu \mathrm{m}$ atau pada $\mathrm{PM}_{2.5}$, usulan Baku mutu logam berat di udara ambien disajikan pada Tabel 7.

\section{UCAPAN TERIMA KASIH}

Kajian baku mutu logam berat ini didorong dengan adanya kegiatan pemantauan logam berat di udara ambien yang dilakukan oleh Pusarpedal bekerjasama dengan PTNBR Batan Bandung, penulis mengucapkan terimakasih banyak telah mendapatkan banyak informasi dan ide dari laporan yang telah dibuat oleh Pusarpedal dan PTNBR Batan Bandung. Penulis juga mengucapkan terimakasih kepada seluruh personil bidang pemantauan Pusarpedal, dan PTNBR Batan Bandung serta semua pihak yang telah membantu terlaksananya kegiatan ini. 
Tabel 7. Usulan Baku Mutu Logam Berat Di Udara Ambien

\begin{tabular}{lllllll}
\hline \multirow{2}{*}{ No } & \multirow{2}{*}{ Parameter } & \multirow{2}{*}{ Satuan } & \multicolumn{2}{c}{ Kadar Maksimum pada TSP } & \multicolumn{2}{l}{ Kadar Maksimum pada PM $_{2.5}$} \\
\cline { 4 - 7 } & & & 1 tahun & 24 jam & 1 tahun & 24 jam \\
\hline 1 & Timbal $(\mathrm{Pb})$ & $\mu \mathrm{g} / \mathrm{m}^{3}$ & 0.5 & 1 & 0.25 & 0.5 \\
2 & Arsen $(\mathrm{As})$ & $\mu \mathrm{g} / \mathrm{m}^{3}$ & 0.006 & 0.3 & 0.00006 & 0.0125 \\
3 & Kadmium $(\mathrm{Cd})$ & $\mu \mathrm{g} / \mathrm{m}^{3}$ & 0.005 & 2 & 0.00005 & 0.02 \\
4 & Merkuri $(\mathrm{Hg})$ & $\mu \mathrm{g} / \mathrm{m}^{3}$ & 1 & 0.5 & 0.005 & 0.01 \\
5 & Kromium $(\mathrm{Cr})$ & $\mu \mathrm{g} / \mathrm{m}^{3}$ & 0.01 & 1.5 & 0.0001 & 0.005 \\
6 & Mangan $(\mathrm{Mn})$ & $\mu \mathrm{g} / \mathrm{m}^{3}$ & 0.15 & 2.5 & 0.00015 & 0.0078 \\
7 & Nikel $(\mathrm{Ni})$ & $\mu \mathrm{g} / \mathrm{m}^{3}$ & 0.02 & 2 & 0.0002 & 0.015 \\
\hline
\end{tabular}

\section{DAFTAR PUSTAKA}

(1) European Environment Agency-EEA Technical report, No.12/2011, Air Quality in Europe-2011 report, Heavy metal-page 56

(2) WHO, 2007, Health risks of heavy metals from longrange transboundary air pollution, Joint WHO Convention Task Force on the Health Aspects of Air Pollution (http://www.euro.who.int/_data/ assets/pdf_file/0007/78649/E91044. pdf) accessed 1 August 2011.

(3) Peraturan Pemerintah Republik Indonesia No. 41/1999 tentang Pengendalian Pencemaran Udara

(4) Press Release KPBB, Bertahan Hidup di Zona merah; Paparan timbel dan dampaknya dari daur ulang aki bekas. 27 Januari 2011.

(5) The Study on The Integrated Air Quality Management for Jakarta Metropolitan Area, JICA, Environmental impact Management Agency (Bapedal), 1997.
(6) Muhayatun Santoso, Diah Dwiana Lestiani, Rita Mukhtar, Esrom Hamonangan, Halimah Syafrul, Andreas Markwitz, Philip K. Hopke, Preliminary study of the sources of ambient air pollution in Serpong, Indonesia, Atmospheric Pollution Research 2 (2011) 190-196

(7) US EPA. 1996. Air Quality Criteria for Particulate Matter Vol III. EPA/600/ P-95/001cF. http://www.epa.gov. Accessed < Juni, 12, 2013>

(8) A Tri-Tugaswati, S Suzuki, H Koyama and T Kawada, Health Effects of Air Pollution due to Automotive Lead in Jakarta, Asia Pac J Public Health $1987 ; 1 ; 23$

(9) Muhayatun Santoso, Diah Dwiana Lestiani, Andreas Markwitz, Lead concentration in ambient air from suburban site in Lembang, Indonesia during 2005-2007.

(10) A k ir a K O N D, E s rom HAMONANGAN, Satoshi SODA, Akikazu KAGA, Yoshio INOUE, Masaharu EGUCHI, Yuta YASAKA, Impacts of converting from leaded to unleaded gasoline on ambient lead concentrations in Jakarta metropolitan area, Journal of Environmental Sciences 19(2007) 709-713 